\title{
Physiological Responses During a Light Muscular Exercise in Conditions of Air Temperature between $20^{\circ} \mathrm{C}$ and $28^{\circ} \mathrm{C}$
}

\author{
Tadakatsu OHNaka, Yutaka Tochinara, \\ Shinya Yamazaki, Masatoshi Tanaka, \\ Keiichi Yoshida, Shokichi OGawA* \\ and Yasutaka OsADA* \\ Department of Hygiene, School of Medicine, Showa University \\ *Department of Physiological Hygiene, the Institute of \\ Public Health
}

\begin{abstract}
Eight male students, wearing only shorts, were exposed to $20,22,24$, 26 , and $28^{\circ} \mathrm{C}$ for 90 minutes on separate days. Relative humidity was $50 \%$ and air velocity was less than $20 \mathrm{~cm} / \mathrm{sec}$. Subjects kept rest in sitting posture for 60 minutes and then took a light fixed work (40W) for 30 minutes on a bicycle ergometer. Their exercise metabolic rate, heart rate, rectal temperature, and mean skin temperature were measured. Measurements between the 25 th and 30 th minute of exercise were used for statistical analyses.

Metabolic rate at $26^{\circ} \mathrm{C}$ was significantly lower than that at $20,22,24$, and $28^{\circ} \mathrm{C}$. Heart rate, rectal temperature, and mean skin temperature increased progressively in cooperate with rising of environmental temperature. Linear relationship was observed between air temperature and heart rate. This results means that under conditions of air temperature between $20^{\circ} \mathrm{C}$ and $28^{\circ} \mathrm{C}$ the metabolic rate during a light muscular exercise is influenced by the environmental temperature similar to the cases of heart rate and body temperature.
\end{abstract}

\section{INTRODUCTION}

The effects of hot environments on metabolic responses and physiological reactions to muscular exercise have been frequently studied (see Whydнam 1973, Rowell 1974). Contradictory findings were, however, reported in literatures regarding metabolic responses during muscular exercise in hot environment. Under these conditions, some workers have re-

Article No. 8206 ported an increase in metabolic rate (Consolazio et al. 1963, Kuroda et al. 19 73, SAto et al. 1980), others a decrease (Brouha et al. 1960, Williams et al. 19 62, Petersen et al. 1973, Gupta et al. 19 77), still others no change (ROWELL et al. 1965, 1969, Strydom et al. 1966, Klausen et al.1967, Sato and Iwamoto 1976). In these studies, metabolic rates during muscular exercise in hot environment were compared with those in "neutral" thermal environments (control values). However, 
"neutral" thermal environment in which control values were obtained was different from each other in these studies. A careful attention has not been paid to these differences in "neutral" air temperature conditions. In our earlier study on resting metabolism in conditions of air temperature between $20^{\circ} \mathrm{C}$ and $28^{\circ} \mathrm{C}$ at intervals of $2^{\circ} \mathrm{C}$, we observed that physiological functions such as metabolic rate, heart rate, sweat rate, and body temperature were influenced by changes in air temperature under these air temperature conditions (OHNAKa et al. 1981). On the other hand, studies on the effects of air temperature on metabolic response during muscular exercise under "neutral" air temperature range were limited in number. Hence, the present study was undertaken to compare the physiological reactions to muscular exercise in conditions of air temperature between $20^{\circ} \mathrm{C}$ and $28^{\circ} \mathrm{C}$ at intervals of $2^{\circ} \mathrm{C}$.

\section{METHOD}

Subjects were eight healthy male students. Their physical characteristics with maximal oxygen intakes were given in Table 1. Maximal oxygen intake was calculated according to the formula of SATo et al.(1980). The subjects, wearing only shorts, were exposed to $20,22,24,26$ and $28^{\circ} \mathrm{C}\left( \pm 0.5^{\circ} \mathrm{C}\right)$ in a climatic chamber for 90 minutes on separate days. Relative humidity was $50 \%$ and air velocity was less than $20 \mathrm{~cm} / \mathrm{sec}$. They sat for 60 minutes before the onset of exercise: 50 minutes in a chair and 10 minutes on the bicycle ergometer to permit adjustment
Table 1. Physical characterictics of eight subjects with maximal oxygen intakes $\left(\mathrm{VO}_{2}\right.$ $\max$ ) and relative work loads (RWL).

\begin{tabular}{cccccc}
\hline Subject & $\begin{array}{c}\text { Age } \\
(\mathrm{yrs})\end{array}$ & $\begin{array}{c}\mathrm{Height} \\
(\mathrm{cm})\end{array}$ & $\begin{array}{c}\text { Weight } \\
(\mathrm{cm})\end{array}$ & $\begin{array}{c}\mathrm{VO}_{2} \mathrm{max} \\
(\mathrm{l} / \mathrm{min})\end{array}$ & $\begin{array}{c}\mathrm{RWL}^{*} \\
(\%)\end{array}$ \\
\hline $\mathrm{A}$ & 19 & 172 & 56.1 & 2.34 & 29.4 \\
$\mathrm{~B}$ & 19 & 172 & 75.4 & 3.37 & 24.4 \\
$\mathrm{C}$ & 19 & 177 & 54.8 & 2.37 & 29.9 \\
$\mathrm{D}$ & 22 & 170 & 54.4 & 2.52 & 28.1 \\
$\mathrm{E}$ & 19 & 165 & 63.1 & 2.66 & 26.9 \\
$\mathrm{~F}$ & 19 & 166 & 53.2 & 2.88 & 25.7 \\
$\mathrm{G}$ & 20 & 170 & 62.7 & 2.70 & 27.0 \\
$\mathrm{H}$ & 18 & 171 & 61.1 & 2.51 & 30.4 \\
mean & 19.2 & 170.4 & 60.1 & 2.67 & 27.7 \\
S D & 1.2 & 3.7 & 7.3 & 0.33 & 2.1 \\
\hline
\end{tabular}

* Relative work loads were presented in percent their maximal oxygen intakes.

to the environmental conditions. The exercise consisted of pedaling a magnetic brake bicycle ergometer at a rate of 60 rpm at a constant load of 40 Watt for 30 minutes. Expressed in percent of their maximal oxygen intakes of the exercise, subjects worked at a level of $27.7 \%$ (24. 4-30.4\%), and these values were also presented in Table 1. The expired volume and the fraction of $\mathrm{O}_{2}$ and $\mathrm{CO}_{2}$ in the expired air were measured continuously by a spirometer (Fukuda Sangyo CR-20) and a $\mathrm{O}_{2}$ and $\mathrm{CO}_{2}$ analyzer (Fukuda Irika Respirizer BM-10). For calculation of metabolic rate, the caloric equivalent of oxygen used was estimated from the value of R.Q. Rectal temperature was recorded by means of a thermister inserted to a depth of $10 \mathrm{~cm}$ into the subjects' rectum. Ten skin thermisters were attached to the subjects : 1 , forehead; 2 , shoulder ; 3 , chest ; 4 , epigastium ; 5 , abdomen ; 6 , forearm ; 7 , hand; 8 , thigh; 9 , leg; 10 , foot. The 
relative contribution of each area was analyzed by calculating the analysis of weighted in calculation of mean skin variance and $t$-values. The analysis of temperature ( $\bar{T}_{s}$ ) as follows (KURATA and variance was performed with respect to FunAzU 1953)

$$
\begin{aligned}
& \overline{\mathrm{T}}_{\mathrm{s}}=0.098 \mathrm{~T}_{1}+0.082 \mathrm{~T}_{2}+0.166 \mathrm{~T}_{3}+0.081 \mathrm{~T}_{4} \\
& +0.081 \mathrm{~T}_{5}+0.061 \mathrm{~T}_{6}+0.053 \mathrm{~T}_{7}+0.172 \mathrm{~T}_{8} \\
& +0.134 \mathrm{~T}_{9}+0.072 \mathrm{~T}_{10} \text { with } \mathrm{T}_{1}-\mathrm{T}_{10} \text { as } \\
& \text { indicated above. }
\end{aligned}
$$

Heart rate was obtained from the electrocardiogram using chest leads. The order of exposure to five different air temperature conditions was randomized for each of the subject. Measurements between the 25 th and 30 th minute of exercise were air-temperature and different individuals. Experiments were carried out during September.

\section{RESULTS AND DISCUSSION}

Rectal temperature ( $\mathrm{Tr}$ ), mean skin temperature $\left(\overline{\mathrm{T}}_{\mathrm{s}}\right)$, metabolic rate $(\dot{\mathrm{M}})$, and heart rate (HR) were presented in Table 2. According to analyses of variance for individual factor on these measurements, the significant differences a-

\begin{tabular}{|c|c|c|c|c|c|c|c|c|c|c|}
\hline \multirow[b]{2}{*}{ Air temp. $\left({ }^{\circ} \mathrm{C}\right)$} & \multicolumn{5}{|c|}{ Rectal Temperature $\left({ }^{\circ} \mathrm{C}\right)$} & \multicolumn{5}{|c|}{ Metabolic Rate $\left(k c a ! / \mathrm{m}^{2} \cdot \mathrm{hr}\right)$} \\
\hline & 20 & 22 & 24 & 26 & 28 & 20 & 22 & 24 & 26 & 28 \\
\hline \multicolumn{11}{|l|}{ Subject } \\
\hline A & 36.7 & 36.5 & 36.4 & 36.9 & 36.8 & 131.00 & 129.72 & 128.04 & 124.14 & 128.72 \\
\hline $\mathrm{B}$ & 37.1 & 36.9 & 37.3 & 37.4 & 37.1 & 141.83 & 136.68 & 137.08 & 132.11 & 129.38 \\
\hline $\mathrm{C}$ & 37.3 & 37.1 & 37.3 & 37.7 & 37.7 & 141.18 & 130.21 & 129.37 & 127.99 & 128.26 \\
\hline $\mathrm{D}$ & 37.2 & 37.3 & 37.1 & 37.1 & 37.6 & 141.80 & 136.21 & 136.99 & 129.42 & 136.63 \\
\hline $\mathrm{E}$ & 37.1 & 37.3 & 37.3 & 37.4 & 37.4 & 142.53 & 139.83 & 148. 64 & 142.88 & 148.61 \\
\hline $\mathrm{F}$ & 37.1 & 37.1 & 37.5 & 37.3 & 37.5 & 152.72 & 146.04 & 142.64 & 140.45 & 141.78 \\
\hline G & 37.3 & 37.1 & 37.2 & 37.2 & 37.2 & 140.49 & 129.75 & 127.04 & 127.88 & 129.73 \\
\hline $\mathrm{H}$ & 37.2 & 37.4 & 37.4 & 37.3 & 37.4 & 140.63 & 137.25 & 133.29 & 132.88 & 143.63 \\
\hline mean & 37.1 & 37.1 & 37.2 & 37.3 & 37.3 & 141.52 & 135.71 & 135. 39 & 132.22 & 135.84 \\
\hline \multirow[t]{2}{*}{ S D } & 0.19 & 0.29 & 0.34 & 0.23 & 0.29 & 5.85 & 5.72 & 7.54 & 6.46 & 7.99 \\
\hline & \multicolumn{5}{|c|}{ Mean Skin Temperature $\left({ }^{\circ} \mathrm{C}\right)$} & \multicolumn{5}{|c|}{ Heart Rate (beats/min) } \\
\hline A & 28.8 & 30.3 & 31.2 & 32.2 & 33.4 & 93 & 94 & 99 & 97 & 101 \\
\hline $\mathrm{B}$ & 28.8 & 39.6 & 32.0 & 31.7 & 32.5 & 99 & 93 & 99 & 102 & 94 \\
\hline $\mathrm{C}$ & 29.2 & 30.7 & 31.8 & 31.8 & 33.0 & 103 & 108 & 109 & 107 & 121 \\
\hline $\mathrm{D}$ & 29.0 & 31.0 & 32.0 & 32.4 & 33.6 & 100 & 101 & 104 & 103 & 111 \\
\hline $\mathrm{E}$ & 29.8 & 30.6 & 31.9 & 32.1 & 32.7 & 101 & 102 & 104 & 104 & 106 \\
\hline $\mathrm{F}$ & 29.3 & 30.8 & 32.1 & 32.7 & 34.3 & 99 & 102 & 104 & 108 & 115 \\
\hline $\mathrm{G}$ & 29.3 & 30.8 & 31.1 & 33.3 & 33.7 & 96 & 95 & 92 & 111 & 108 \\
\hline $\mathrm{H}$ & 29.2 & 31.4 & 31.8 & 33.1 & 33.7 & 100 & 112 & 123 & 111 & 110 \\
\hline mean & 29.2 & 30.8 & 31.7 & 32.4 & 33.4 & 98.9 & 100.9 & 104.3 & 105.4 & 108.3 \\
\hline S D & 0.32 & 0.33 & 0.38 & 0.58 & 0.60 & 3.1 & 6.8 & 9.1 & 4.8 & 8.3 \\
\hline
\end{tabular}
used for the analyses. The results were mong individuals were found in all meas-

Table 2. Rectal temperature, mean skin temperature, metabolic rate and heart rate of eight subjects during exercise in five air temperature conditions. 


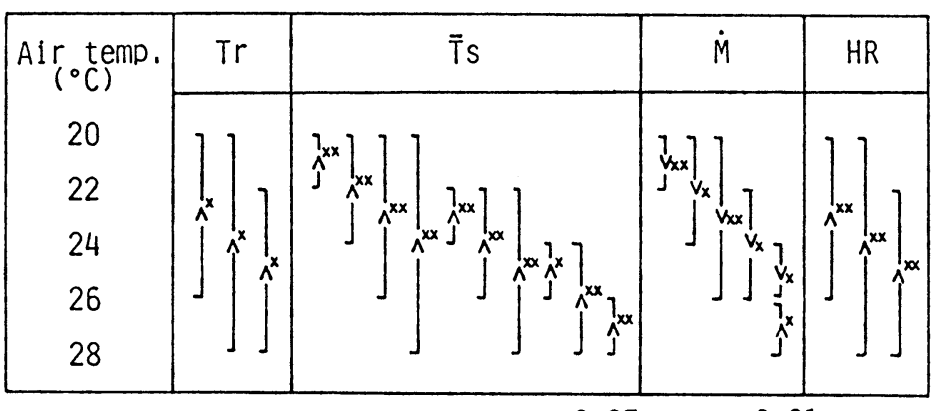

$x p<0.05 \quad x \times p<0.01$

Fig 1. Significant differences of rectal temperature ( $T r$ ), mean skin temperature $\left(\overline{\mathrm{T}}_{\mathrm{S}}\right)$, metabolic rate $(\dot{\mathrm{M}})$ and heart rate $(H R)$ in five air temperature conditions.

urements $(\mathrm{Tr}: \mathrm{F}=10.24, \mathrm{P}<0.01, \mathrm{Ts}: \mathrm{F}=$ 4.00, $\mathrm{P}<0.01, \mathrm{M}: \mathrm{F}=15.85, \mathrm{P}<0.01, \mathrm{HR}$ : $\mathrm{F}=5.98, \mathrm{P}<0.01)$. Statistical comparisons of these measurements between air temperatures were, therefore, performed using a paired $t$-test, and the significant differences between the values under five air temperature conditions are shown in Fig. 1.

At pre-exercise rest, rectal temperature was not significantly different in five air temperature conditions, that is, rectal temperature (mean $\pm \mathrm{SD}$ ) at $20^{\circ} \mathrm{C}$ Ta were $37.13 \pm 0.25^{\circ} \mathrm{C}, 37.14 \pm 0.25^{\circ} \mathrm{C}$ at $22^{\circ} \mathrm{C}$ Ta, $37.26 \pm 0.14^{\circ} \mathrm{C}$ at $24^{\circ} \mathrm{C} \mathrm{Ta}, 37.21 \pm 0.17^{\circ} \mathrm{C}$ at $26^{\circ} \mathrm{C}$ Ta, and $37.26 \pm 0.27^{\circ} \mathrm{C}$ at $28^{\circ} \mathrm{C}$ Ta, respectively. Rectal temperature fell gradually during the initial 10 minute of exercise, then increased during the period from 10th to 20th minute of exercise. After 20th minute of exercise, rectal temperature remained at each relatively steady level in five air temperature conditions. At the end of exercise, rectal temperatures at $26^{\circ} \mathrm{C} \mathrm{Ta}$ and $28^{\circ} \mathrm{C} \mathrm{Ta}$ were significantly higher than that at $20^{\circ} \mathrm{C} \mathrm{Ta}$, and at $28^{\circ} \mathrm{C}$
Ta was higher than that at $22^{\circ} \mathrm{C}$ Ta. It is well known that body temperature typically stabillzes at an elevated level during exercise. NiELSEN (1938) showed that exercising man exhibits a stable elevated rectal temperature throughout long periods of exercise. NiELSEN also showed that this elevated temperature was rather independent of environmental changes; over a wide range of conditions, only small deviations of rectal temperature above normal were observed. $\mathrm{KI}_{\text {- }}$ TZING et al. (1968) observed that esophageal temperature which respond much more rapidly than rectal temperature, maintained during exercise was influenced by enviroumental temperatures ranged from $-4^{\circ} \mathrm{C}$ to $32^{\circ} \mathrm{C}$ Ta. In the present study, rectal temperatures during exercise at $26^{\circ} \mathrm{C}$ and $28^{\circ} \mathrm{C}$ were higher than those at $20^{\circ} \mathrm{C}$ or $22^{\circ} \mathrm{C}$. It was confirmed that the temperature maintained during exercise was influenced by environmental temperature (BRENGELMANN 1977) under air temperature conditions ranged from $20^{\circ} \mathrm{C}$ to $28^{\circ} \mathrm{C}$. 
Mean skin temperature at pre-exercise rest at $20^{\circ} \mathrm{C}$ Ta was $29.19 \pm 0.29^{\circ} \mathrm{C}$, and it increased to $33.24 \pm 0.40^{\circ} \mathrm{C}$ at $28^{\circ} \mathrm{C}$ Ta. The time course of mean skin temperature during exercise was similar to that of rectal temperature. The correlation coefficient between mean skin temperature and air temperature was highly significant $(\mathrm{r}=0.938 ; \mathrm{P}<0.001)$.

Metabolic rate during exercise at $26^{\circ} \mathrm{C}$ Ta was significantly lower than at 20,22 , 24 , and $28^{\circ} \mathrm{C} \mathrm{Ta}$. When man was exposed to cold, his heat production increased in order to maintain heat balance. It seems that in the 20,22 and $24^{\circ} \mathrm{C}$ environments where no shivering occurred, there is a tensing of the muscles (Winslow and Herrington 1949). We also observed an increase in metabolic rate at $28^{\circ} \mathrm{C} \mathrm{Ta}$. Although some workers observed the increase in metabolic rate during exercise in hot environment as compared with a control value, the air temperature at which they observed the increase in metabolic rate was considerably high. Consolazio et al. (1963) showed that there was a significantly higher metabolic rate during exercise at $37.7^{\circ} \mathrm{C}$ Ta than at $29.4^{\circ} \mathrm{C} \mathrm{Ta}$ or $21.1^{\circ} \mathrm{C}$ Ta. Kuroda et al. (1973) found that metabolic rate at $40^{\circ} \mathrm{C}$ Ta was somewhat higher than at $20^{\circ} \mathrm{C}$ Ta or $30^{\circ} \mathrm{C}$ Ta. SATo et al. (1980) found an increase in metabolic rate at $35^{\circ} \mathrm{C} \mathrm{Ta}$ as compared with at $15^{\circ} \mathrm{C} \mathrm{Ta}$.

Others showed no change in metabolic rate during exercise in hot environment as compared with control value. KLUSEN et al. (1967) showed that metabolic rate during exercise was approximately the same in heat $\left(32.1^{\circ} \mathrm{C} \mathrm{Ta}\right)$ as in the control $\left(24.8^{\circ} \mathrm{C}\right.$ Ta). MiURA et al. (1972) tested the effects of air temperature under conditions of air temperature under conditions of air temperature between $5^{\circ} \mathrm{C}$ and $40^{\circ} \mathrm{C}$ at intervals of $5^{\circ} \mathrm{C}$, and found an increase of metabolic rate during exercise in only the coldest condition. STRYDOM et al. (1966) revealed no change of metabolic rate under conditions of air temperature between $29.4^{\circ} \mathrm{C}$ and $36.1^{\circ} \mathrm{C}$.

In contrast with these findings, Willams et al. (1962) found a lower metabolic rate during exercise at $36.1^{\circ} \mathrm{C}$ Ta than that at $21.1^{\circ} \mathrm{C}$ effective temperature. BRouHA et al. (1960) found that metabolic rate at $37.2^{\circ} \mathrm{C} \mathrm{Ta}$ was significantly lower than that at $25^{\circ} \mathrm{C}$ Ta.

Since a metabolic rate in hot environment was compared with a control value which was obtained in different air temperature conditions an increase in metabolic rate which was observed at $28^{\circ} \mathrm{C}$ Ta in this study might have been failed to be noticed.

Heart rate at $26^{\circ} \mathrm{C}$ and $28^{\circ} \mathrm{C}$ were higher than that at $20^{\circ} \mathrm{C}$, and at $28^{\circ} \mathrm{C}$ also higher than that at $22^{\circ} \mathrm{C}$. A linear relationship was observed between heart rate and air temperature $(\mathrm{r}=0.431, \mathrm{P}<0.01)$, which agrees with DiLl (1942) who showed that heart rate during exercise increased with elevating air temperature above $20^{\circ} \mathrm{C}$ environment.

In our earlier study on resting metabolism in conditions of air temperature between $20^{\circ} \mathrm{C}$ and $28^{\circ} \mathrm{C}$, metabolic rate at rest in the 24 and $26^{\circ} \mathrm{C}$ environments were significant lower than that at 20,22 
and $28^{\circ} \mathrm{C}$. (OHNAKA et al. 1981). Under these experimental conditions, physiolog. ical functions such as metabolic rate, body temperature and heart rate were influenced by changes in air temperature under conditions of air temperature between $20^{\circ} \mathrm{C}$ and $28^{\circ} \mathrm{C}$. In the studies on effects of high or low air temperature conditions on physiological functions, conditions air temperature between $20^{\circ} \mathrm{C}$ and $28^{\circ} \mathrm{C}$ were adopted as control thermal conditions frequently. It means that differences in physiological functions among these thermal conditions have to be taken into consideration in evaluating effects of high or low air temperature on physiological functions at least at rest or during a light exercise.

This study was supported in part by a grant from Science Foundation, the Ministry of Education in Japan.

\section{REFERENCES}

Brengelmann, G. L., 1977 : Control of sweating rate and skin blood flow during exercise, In: Problems with temperature regulation during exercise edite by NADEL, E. R., Academic Press, New York, 27-48.

Brooks, G. A., K. J. HittlumanN, J. A, FaulkNER and R. E. BEyer, 1971: Temperature, skeletal muscle mitochondrial functions, and oxygen debt. Am. J. Physiol., 220: 1053-1059.

Brouha, L., P.E. Smith Jr, R. De LANne and M. E. Maxfild, 1960: Physiological reactions of men and romen during muscular activity and recovery in various environments. J. A ppl. Physiol. 16: 133-140.

Consolazio, C. F., R. O. Matoush, R. A. NelSON, J. B. TORRES and G. J. Is A AC, 1963: Environmental temperature and energy expenditures. J. A ppl. Physio!., 18: 65-68.
DilL, D. B., 1942: Effects of physical strain and high altitudes on the heart and circulation. A. Heart J., 23: 441-454.

Gupta, J. S., G.P. Dimri and M.S. Malhotra, 1977: Metabolic responses of Indians during sub-maximal and maximal work in dry and humid heat. Ergonomics, 20: 33-40.

Kla ausen, K., D. B. Dill, E. E. Phillips Jr and D. McGREGOR, 1967: Metabolic reactions to work in the desert. J. Appl. Physiol., 22: 292296.

Kitzing, J., D. Kutta and A. Bleichert, 1968: Temperaturregulation bei langdauernder schwerer korperlicher Arbeit. Pflugers Arch., 301: 241-253.

Kurata, S. and Y.Funatsu, 1953: A practical method of evaluting mean skin temperature. J. Sci. Labour, 30: $332-337$ (In Japanese with English abstract).

KurOda, Y., K. TSUKagOShI, Y. SUzUKI and T. AMAMiYA, 1973: Effects of ambient tem. perature on sustained exercise Part III. Showa 47 nendo nihon taiiku kyokai sports kagaku kenkyu hokoku No. X: 27-57 (in Japanese).

〔黑田善雄，塚越克己・鈴木洋児・雨宮輝也，1973 : 環境温度が持久性運動に及ぼす影響一第 3 報一・ 昭和 47 年度 日本体育協会スポーツ科学研究報 告 No. X : $27-57$

Miura, T., K. Kimotsuki, A. Watanabe, K. Numa jiri, K. Matsumoto and H. Nomura, 1972: Effect of the ambient temperature ranging $5^{\circ}-40^{\circ} \mathrm{C}$ with relative humidity of $50-60 \%$ on the phsiological functions of men. J. Sci. Labour, 48: 103-136 (In Japanease with English abstract).

Nielsen, M., 1938: Die Regulation der Korpertemperatur bei Muskelarbeit. Skand. Arch. Physiol., 79: 193-230.

Ohnaka, T., Y. Tochihara, S. Yamazaki, M. TANAKA, K. Yoshida, S. Ogawa and Y. OsaDA, 1981: Resting metabolism in conditions of air temperature between 20 and $28^{\circ} \mathrm{C}$. J. Anthrop. Sci. Nippon, 89: 377-384.

Petersen, E. S. and H. V. Christensen, 1973: Effect of body temperature on steady state ventilation and metabolism in exercises. 
Acta Physiol. Scand., 89: 342-351.

Rowell, L. B., J. R. Blackmon, R. H. MARTin, J. A. MAzzarella and R. A. Bruce, 1965: Hepatic clearance of indocyanine green in man under thermal and exercise stresses. J. Appl. Physiol., 20: 384-394.

Rowell, L. B., G. L. Brengelmann, J. A. MurRAY, K. K. KRANING II and F. KUSUMI, 1969: Human metabolic responses to hyperthermia during mild to maximal exercise. J. Appl. Physiol., 26: 395-402.

Rowell, L. B., 1974: Human cardiovascular adjustments to exercise and thermal stress. Physiol. Rev., 54: 75-159.

Sato, H., N. NARAKI, Y. TAKASAKI, T. OHNAKA and M. YAMASAKI, 1980: Effects of thermal environment on physiological reactions to muscular work. J. Anthrop. Sci. Nippon, 88: 65-374.

SAto, M. and Y. Iwamoto, 1976: Combined influences of ambient temperature and graded work on cardiopulmonary functions. J. Hu- man Ergol., 5: 61-70.

SATo, M., A. Yasukouch and H. HARAdA, 1980: Prediction of maximal oxygen intake over a wide range of air temperature con. ditions. J. Human Ergol.9: 81-89.

Strydom, N. B., C. H. Wyndham, C. G. WilLiams, J.F. Morrison, G. A. G. Bredell, M. J.RAHDEN and J.Peter, 1966: Energy requirements of acclimatized subjects in humid heat. Feb. Proc., 25: 1366-1371.

Williams, C. G., G. A. G. Bredell, C. H. Wyndham, N. B. Strydom, J. F. MORRISON, J. Peter, P. W. Fleming and J.S.WARD, 1962 : Circulatory and metabolic reactions to work in heat., J, A ppl. Physiol., 17 : 625-638.

Winslow G. E. A. and L.P. Herrington, 1949 : Temperature and human life. Princeton University Press, Princeton, 23-25.

Wyndham, C. H., 1973: The Physiology of exercise under heat stress. Ann. Rev. Physiol., 35: 193-220.

(Received March 30, 1982)

気温20〜 $28^{\circ} \mathrm{C}$ に打ける軽作業時生理反応

\author{
大中忠勝・杤原 裕・山崎信也・田中正敏 \\ 吉田敬一・小川庄吉*・長田泰公* \\ 昭和大学・医学部・衛生学教室 \\ *国立公衆衛生院・生理衛生学部
}

8 名の男子大学生を被検者とし，人工気候室に执いて気温 $20,22,24,26$ 及び $28^{\circ} \mathrm{C}$ の環境下で 60 分間の安 静坐位ののち，40Wの自転車エルゴメータ作業を 30 分間行わせた。相対湿度は $50 \%$ ，気流は $20 \mathrm{~cm} / \mathrm{sec}$ 以下に 保った。被検者の衣服は短パンのみとし，作業中の直腸温，平均皮膚温，代謝量及び心拍数を測定した。各測 定値は作業終了前 5 分間について検討された。

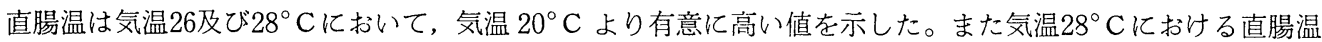

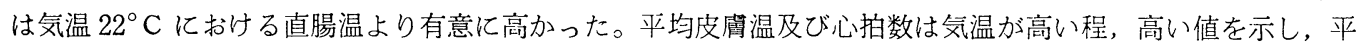

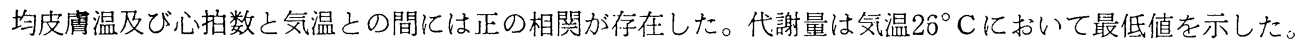

従来の作業時生理機能に及ぼす低温及び高温の影響得する関究において, 対照として採用されるてとの多 い気温条件の範囲内 $\left(20 \sim 28^{\circ} \mathrm{C}\right)$ においても，作業時の生理機能が気温の影響を受けることが示された。特 にそれらの条件下において，体温や心拍数のみならず代謝量においても気温の影響が存在するてとが示され た。 